\title{
Powder for Oral Suspension Dosage Form
}

National Cancer Institute

\section{Source}

National Cancer Institute. Powder for Oral Suspension Dosage Form. NCI Thesaurus.

Code C64908.

A powder that yields a suspension intended for oral administration following reconstitution. 